\title{
$\beta$ - $N$-Acetylhexosaminidases of Physarum polycephalum: Some Characteristics of a New Form of the Enzyme
}

\author{
By GEOFFREY A. COOK,${ }^{1} \dagger$ ANTHONY M. S. POPE ${ }^{2}$ AND \\ JOHN L. STIRLING ${ }^{1 *}$ \\ ${ }^{1}$ Department of Biochemistry, Queen Elizabeth College, University of London, Campden Hill, \\ London W8 7 AH, U.K. \\ ${ }^{2}$ G. D. Searle \& Co. Ltd, Research Division, Lane End Road, High Wycombe, \\ Bucks HP12 4HL, U.K.
}

(Received 13 April 1982; revised 1 September 1982)

\begin{abstract}
During axenic growth, microplasmodia of Physarum polycephalum secreted chitinase and $\beta-N$ acetylhexosaminidase. Chitin added to the medium was depolymerized to $N$-acetylglucosamine, but this was not used for growth. Spent culture medium contained three enzymes with activity towards 4-methylumbelliferyl- $\beta$ - $N$-acetylglucosaminide and these were separated by chromatography on DEAE-cellulose. In previous work $\beta$ - $N$-acetylhexosaminidases $\mathrm{X}$ and $\mathrm{Y}$ were identified. The latter form has now been resolved to yield a new form $Z$. The $Y$ form can be readily distinguished from both $\mathrm{X}$ and $\mathrm{Z}$ by its lack of activity towards $N, N^{\prime}$-diacetylchitobiose. Comparison of $\beta-N$-acetylhexosaminidases $\mathrm{X}$ and $\mathrm{Z}$ revealed differences in thermal stability, $\mathrm{pH}$ optima and $K_{\mathrm{m}}$ values. 3,4-Dinitrophenyl-tetra- $N$-acetylchitotetraoside is hydrolysed by $\beta$ $\mathrm{N}$-acetylhexosaminidase $\mathrm{Z}$, but not by the $\mathrm{X}$ form of the enzyme.
\end{abstract}

\section{INTRODUCTION}

Physarum polycephalum Schweinitz, a myxomycete or true slime mould, can be cultivated axenically in the form of microplasmodia in a semi-defined medium (Carlile, 1971). The total, and specific, activities of a number of enzymes increase in the medium towards the end of the growth phase; these include ribonucleases (Braun \& Behrens, 1969), proteinases (Farr et al., 1974) and several exoglycosidases of which the $\beta$ - $N$-acetylhexosaminidases are the best characterized (Kilpatrick \& Stirling, 1975, 1977; Kuehn et al., 1977). Two main forms of $\beta-N$ acetylhexosaminidase, $\mathrm{X}$ and $\mathrm{Y}$, are found in the spent culture medium and these are readily separated by electrophoresis or ion-exchange chromatography (Kilpatrick \& Stirling, 1977). Kuehn et al. (1977) have described the purification and properties of extracellular and intracellular forms of $\beta-N$-acetylhexosaminidases from $P$. polycephalum and have suggested on the basis of their reported properties that $\beta$ - $N$-acetylhexosaminidase $\mathrm{X}$ is predominantly extracellular and that $\mathrm{Y}$ is the intracellular form.

In addition to the $\beta$ - $N$-acetylhexosaminidases, $P$. polycephalum produces chitinase (G. A. Cook, A. M. S. Pope \& J. L. Stirling, unpublished work) but it has not been established to what extent the exoglycosidases can participate in the degradation of oligosaccharides arising from depolymerization of chitin. In this paper we describe a previously unknown form of $\beta$ - $N$-acetylhexosaminidase, here called $\mathrm{Z}$, and assess the possible role of all three $\beta$ - $N$-acetylhexosaminidases, $\mathrm{X}, \mathrm{Y}$ and $\mathrm{Z}$, in chitinolysis.

$\dagger$ Present address: Division of Immunochemical Genetics, MRC Clinical Research Centre, Watford Road, Harrow, Middlesex HAl 3UJ, U.K.

Abbreviation: 4-MeUmb- $\beta$-GlcNAc, 4-methylumbelliferyl- $\beta$-D-2-acetamido-2-deoxyglucopyranoside. 


\section{METHODS}

Materials. 3,4-Dinitrophenyl-di- $N$-acetylchitobioside and 3,4-dinitrophenyl-tetra- $N$-acetylchitotetraoside were generous gifts from Mr E. E. Vickers, Koch-Light Laboratories, Colnbrook, U.K. $N, N^{\prime}$-Diacetylchitobiose was purchased from L'Industrie Biologique Francaise, Departement Reactifs, 92115 Clichy, France. 4-Methylumbelliferyl- $\beta$-D-2-acetamido-2-deoxyglucopyranoside was purchased from Koch-Light. Blue Dextran, bovine serum albumin, horseradish peroxidase, d-biotin and methyl $\alpha$-D-glucoside were obtained from Sigma; cytochrome $c$ from BDH; DEAE-cellulose from Whatman; Concanavalin A-Sepharose 4B was purchased from Pharmacia and Biogel P200 from BioRad. Equine haemin and thiamin hydrochloride were from Hopkin \& Williams. General laboratory chemicals were obtained from Fisons Scientific Apparatus and were of AnalaR grade.

Growth of organism. Physarum polycephalum (strain ixA 7029) cultures were maintained as plasmodia on nutrient agar plates and as microplasmodia in liquid culture, according to Carlile (1971). Liquid medium contained (per litre of distilled water): $10 \mathrm{~g}$ D-glucose; $10 \mathrm{~g}$ bacteriological peptone (Oxoid); $3.54 \mathrm{~g}$ citric acid; $2 \mathrm{~g} \mathrm{KH}_{2} \mathrm{PO}_{4} ; 0.9 \mathrm{~g}$ $\mathrm{CaCl}_{2} .6 \mathrm{H}_{2} \mathrm{O} ; 0.6 \mathrm{~g} \mathrm{MgSO}_{4} .7 \mathrm{H}_{2} \mathrm{O} ; 0.244 \mathrm{~g} \mathrm{EDTA}$ disodium salt; $60 \mathrm{mg} \mathrm{FeCl}{ }_{2} .6 \mathrm{H}_{2} \mathrm{O} ; 34 \mathrm{mg} \mathrm{ZnSO} \mathrm{Zn}_{4} .7 \mathrm{H}_{2} \mathrm{O} ; 5 \mathrm{mg}$ d-biotin; $42.4 \mathrm{mg}$ thiamin hydrochloride; $5 \mathrm{mg}$ equine haemin. Spent culture medium was obtained by growing microplasmodia in $50 \mathrm{ml}$ medium in $250 \mathrm{ml}$ conical flasks shaken at 200 r.p.m. and $24^{\circ} \mathrm{C}$ for several days until growth stopped and maximum enzyme yields were achieved. Microplasmodia were removed from the spent culture medium by centrifuging at $500 \mathrm{~g}$ for $5 \mathrm{~min}$. Medium was then centrifuged at $38000 \mathrm{~g}$ for $45 \mathrm{~min}$ to remove the secreted polysaccharide and kept at $4{ }^{\circ} \mathrm{C}$ until required.

Enzyme assays. $\beta$ - $N$-Acetylhexosaminidase (EC 3.2.1.52) was assayed using 4-MeUmb- $\beta$-GlcNAc by the method of Kilpatrick \& Stirling (1977). Enzyme activity towards $N, N^{\prime}$-diacetylchitobiose was determined by incubating enzyme samples $(50 \mu \mathrm{l})$ with $50 \mu \mathrm{l}$ of a $1 \mathrm{mM}$ solution of the disaccharide in $0 \cdot 1 \mathrm{M}$-sodium phosphate/citric acid buffer, $\mathrm{pH} 3.8$, for $30 \mathrm{~min}$ at $37^{\circ} \mathrm{C}$. To this incubation mixture, $50 \mu 10.8 \mathrm{M}$-potassium tetraborate, pH 9.1, was added and the samples boiled for $3 \mathrm{~min}$, then cooled rapidly in an ice/water mixture before $1.2 \mathrm{ml}$ p-dimethylaminobenzaldehyde solution (Reissig et al., 1955) was added. Colour was developed by incubating the reaction mixture at $37^{\circ} \mathrm{C}$ for $25 \mathrm{~min}$ and the absorbance at $585 \mathrm{~nm}$ recorded. Activities towards 3,4-dinitrophenyldi- $N$-acetylchitobioside and 3,4-dinitrophenyl-tetra- $N$-acetylchitotetraoside were assayed by incubating samples

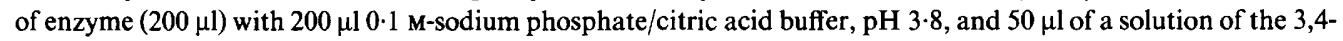
dinitrophenylglycoside. The reaction was stopped by the addition of $0.5 \mathrm{ml} 0.2 \mathrm{M}$-sodium glycinate buffer, $\mathrm{pH} 10 \cdot 4$, and the absorbance read at $400 \mathrm{~nm}$. Release of 3,4-dinitrophenol was linear with time for at least $15 \mathrm{~min}$ under these assay conditions. One unit of enzyme activity is that amount of enzyme that hydrolyses $1 \mu \mathrm{mol}$ substrate $\min ^{-1}$ under these conditions. Chitinase (EC 3.2.1.14) was assayed with ${ }^{3} \mathrm{H}$-labelled colloidal chitin (70000 c.p.m. $\mathrm{ml}^{-1}$ ) prepared by the method of Molano et al. (1977). Chitinase (100 $\mu \mathrm{l}$ ) was incubated with $100 \mu \mathrm{l}$ substrate $\left(10 \mathrm{mg} \mathrm{m}^{-1}\right)$ in $0.1 \mathrm{M}$-sodium phosphate/citric acid buffer, $\mathrm{pH} 4 \cdot 5$, for $2 \mathrm{~h}$ at $37^{\circ} \mathrm{C}$. The digests were then centrifuged at $2000 \mathrm{~g}$ for $5 \mathrm{~min}$ to pellet the residual substrate and $100 \mu \mathrm{l}$ of the supernatant taken for liquid scintillation counting in $7 \mathrm{ml}$ scintillation mixture T (Hopkin \& Williams) using a Packard Tri-Carb model 3375 liquid scintillation spectrometer.

Protein was determined by a modification of the Lowry method in which sodium potassium tartrate was replaced by trisodium citrate. Bovine serum albumin was used as a standard.

Separation of $\beta$-N-acetylhexosaminidases $X, Y$ and $Z$ and partial purification of the $X$ and $Z$ forms. In preparation for ion-exchange chromatography, spent culture medium was dialysed for $24 \mathrm{~h}$ against $10 \mathrm{mM}$-sodium phosphate buffer, pH 8.0 $(2 \times 5$ litre changes $)$. The non-diffusible material was then applied to a column of DEAE-cellulose $(4.5 \times 2.1 \mathrm{~cm}$ diameter) equilibrated in $10 \mathrm{~mm}$-sodium phosphate buffer, $\mathrm{pH} 8 \cdot 0$. The column was then irrigated with $100 \mathrm{ml}$ of this buffer at $35 \mathrm{ml} \mathrm{h}^{-1}$ until unadsorbed protein had been eluted. $\beta$ - $N$-Acetylhexosaminidases were eluted with a linear $\mathrm{NaCl}$ gradient $(0-0.3 \mathrm{M}$ in $400 \mathrm{ml}$ ). Fractions containing the peaks of $\beta$ - $N$-acetylhexosaminidase activity, but excluding fractions containing the overlap between peaks as indicated in Fig. 3, were concentrated using an ultrafiltration cell (Chemlab Instruments Ltd, Hornchurch, Essex) fitted with a G10T membrane. Concentrated peaks of $\beta$ - $N$-acetylhexosaminidase activity were applied separately to a column of Biogel P200 (28 $\times 2.5 \mathrm{~cm}$ diameter) equilibrated with $50 \mathrm{~mm}$-sodium phosphate/citric acid buffer, pH 5.3. Fractions containing $\beta$ $\mathrm{N}$-acetylhexosaminidase activity were pooled, concentrated in an ultrafiltration cell and dialysed against $10 \mathrm{mM}-$ sodium phosphate buffer, pH 6.8, containing $0.5 \mathrm{M}-\mathrm{NaCl}, 0 \cdot 1 \mathrm{M}-\mathrm{CaCl}_{2}, 0 \cdot 1 \mathrm{M}-\mathrm{MnCl}_{2}$ and $0 \cdot 1 \mathrm{mM}-\mathrm{MgCl}_{2}$. Samples were then applied to a column of Concanavalin A-Sepharose $4 \mathrm{~B}(1.8 \times 1.3 \mathrm{~cm}$ diameter $)$ equilibrated with this buffer, and eluted with $0.5 \mathrm{M}$-methyl $\alpha$-D-glucoside in the same buffer.

Preparation of an extract containing intracellular enzymes. Microplasmodia were harvested by filtration on Whatman no. 1 filter paper after $6 \mathrm{~d}$ of culture in axenic medium and before they reached the end of the exponential phase of growth, and the culture medium kept. After washing the microplasmodia with fresh medium, they were subjected to four cycles of freezing and thawing in $50 \mathrm{~mm}$-sodium phosphate/citric acid buffer, $\mathrm{pH} 5 \cdot 2$. The lysed microplasmodia and culture medium were dialysed separately against $5 \mathrm{~mm}$-sodium phosphate buffer, $\mathrm{pH} 8 \cdot 0$, in preparation for chromatography on DEAE-cellulose. 
RESULTS

\section{Enzyme activity and growth}

During culture of $P$. polycephalum as microplasmodia in axenic medium, the extracellular activities of $\beta$ - $N$-acetylhexosaminidase, assayed with both 4-MeUmb- $\beta$-GlcNAc (Fig. $1 c$ ) and $N, N^{\prime}$-diacetylchitobiose (Fig. $1 b$ ), and chitinase (Fig. $1 d$ ) rose steadily throughout growth. It is well known that the organism responds to starvation by forming microspherules (Carlile, 1971) and at this stage there was a marked decrease in the protein detected in the cellular material (Fig. 1 a). However, the rate of appearance of the enzymes in the medium was sustained during formation of microplasmodia.

The participation of extracellular enzymes in the degradation of colloidal chitin was shown by experiments in which microplasmodia were grown in a medium containing chitin $\left(10 \mathrm{mg} \mathrm{ml}^{-1}\right)$ in place of glucose. A lag phase of several days was observed before the culture began to grow (Fig. $1 a$ ) and during this time the turbid suspension of chitin cleared. $\beta$ - $N$-Acetylhexosaminidase and chitinase activities in the medium increased slowly through the lag phase and then at a faster rate as the culture began to grow, although the rate of enzyme production did not keep up with biomass production, measured as protein (Fig. $1 e, f$ ). The second increase in the specific activities of $\beta$ - $N$-acetylhexosaminidase and chitinase was due to a decrease in the detectable protein rather than an increased rate of appearance of the enzymes in the medium. Total $\beta-N$-acetylhexosaminidase activity was fourfold greater in the medium of microplasmodia grown in the presence of chitin than in the standard axenic medium, but chitinase activities were no higher (Fig. 1). Assays for $\beta$ - $N$-acetylhexosaminidase using $N, N^{\prime}$-diacetylchitobiose as the substrate were impossible in flasks containing chitin because the reaction product could not be reliably detected against the background of a high concentration of free $N$-acetylglucosamine in the medium (Fig. 2). The highest concentrations of $N$-acetylglucosamine $\left(11 \mathrm{mg} \mathrm{ml}^{-1}\right.$ at $\left.240 \mathrm{~h}\right)$ corresponded exactly with the concentration expected from the complete depolymerization of chitin. A decrease in the concentration of $\mathrm{N}$-acetylglucosamine accompanied the formation of microspherules.

Samples of the culture medium removed at intervals during the growth of $P$. polycephalum in the presence of chitin, were analysed for chitin oligosaccharides by TLC, but only $N$-acetylglucosamine was detected and there was no evidence of oligosaccharides at any stage of the experiment.

\section{Separation of $\beta$ - $N$-acetylhexosaminidases $X, Y$ and $Z$}

Chromatography of spent culture medium on DEAE-cellulose resolved the $\beta$ - $N$-acetylhexosaminidase activity into three peaks which were detected by their activities towards 4-MeUmb$\beta$-GlcNAc (Fig. 3). The first peak to emerge in the salt gradient was $\beta$ - $N$-acetylhexosaminidase $\mathrm{X}$ (Kilpatrick \& Stirling, 1977) but the form previously designated as $\beta$ - $N$-acetylhexosaminidase $Y$ has been clearly resolved into two peaks under these conditions. We propose to retain the designation $\mathrm{Y}$ for the most acidic of these enzymes and to call the enzyme that has charge properties intermediate between forms $\mathrm{X}$ and $\mathrm{Y}, \beta$ - $N$-acetylhexosaminidase $\mathrm{Z}$. When $N, N^{\prime}-$ acetylchitobiose was used to assay the column fractions, only two peaks of activity were detected (Fig. 3), the smaller peak being eluted with $\beta$ - $N$-acetylhexosaminidase $\mathrm{X}$ and the larger one with $\beta$ - $N$-acetylhexosaminidase $\mathrm{Z}$.

\section{Further purification of the $\beta-N$-acetylhexosaminidase}

$\beta$ - $N$-Acetylhexosaminidases $\mathrm{X}, \mathrm{Y}$ and $\mathrm{Z}$ were indistinguishable by their behaviour on columns of Biogel P200, each of them eluting in a volume corresponding to a molecular weight of $165000 \pm 15000$, determined in comparison with proteins of known molecular weight. In other experiments samples of all three enzymes separated on DEAE-cellulose were retained by columns of Concanavalin A-Sepharose 4B and could be eluted with $0.5 \mathrm{M}$-methyl $\alpha$-D-glucoside. $\beta$ - $N$-Acetylhexosaminidase $\mathrm{Y}$ clearly has a different specificity from forms $\mathrm{X}$ and $\mathrm{Z}$ in that it does not hydrolyse $N, N^{\prime}$-diacetylchitobiose. To establish whether $\beta$ - $N$-acetylhexosaminidases $\mathrm{X}$ and $\mathrm{Z}$ were closely related enzyme forms, as is so for mammalian isoenzymes of $\beta$ - $N$-acetyl- 

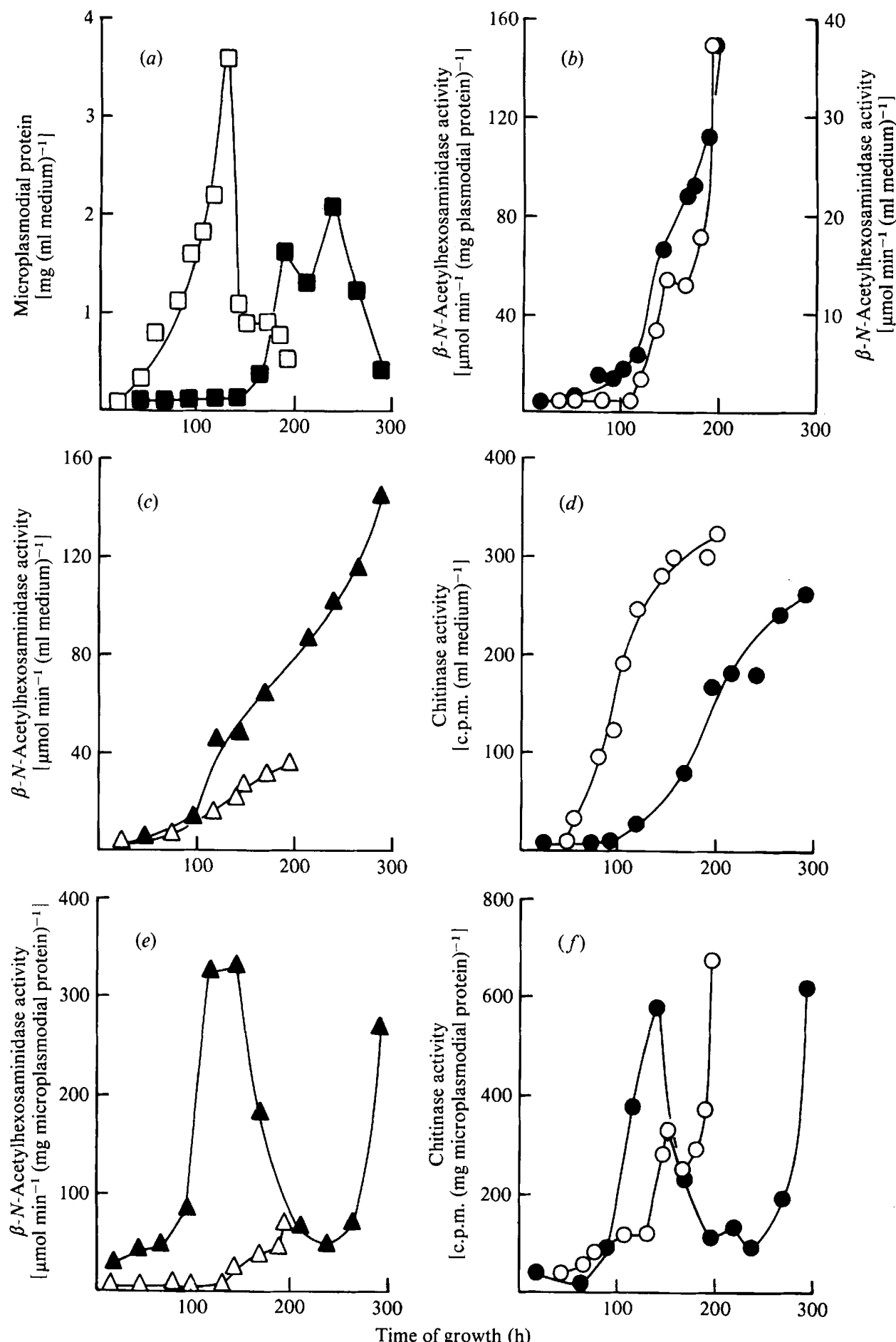

Fig. 1. Extracellular enzyme production by microplasmodia of $P$. polycephalum. Microplasmodia were grown in $50 \mathrm{ml}$ medium containing either glucose (open symbols) or colloidal chitin (closed symbols). (a) Microplasmodial protein; (b) $\beta$ - $N$-acetylhexosaminidase activity assayed using $N, N^{\prime}$-diacetylchitobiose as substrate, expressed per $\mathrm{mg}$ of microplasmodial protein $(\mathrm{O})$ and per $\mathrm{ml}$ of culture medium (O); (c) $\beta$ - $N$-acetylhexosaminidase activity assayed with 4-MeUmb- $\beta$-GlcNAc and expressed per ml of 


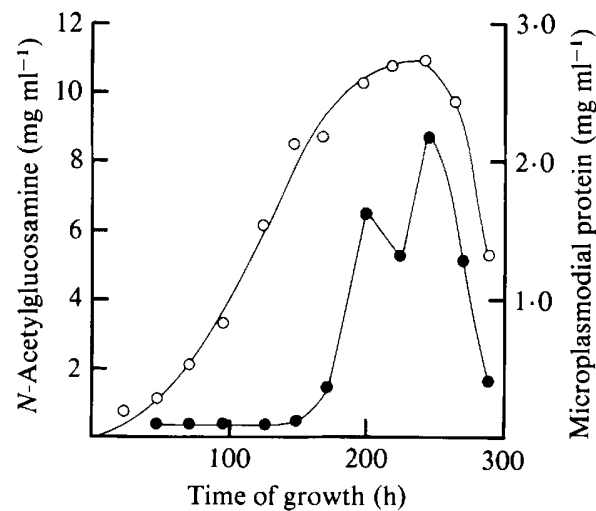

Fig. 2. Concentration of $N$-acetylglucosamine in the culture medium of $P$. polycephalum when grown in the presence of colloidal chitin. Samples of medium were taken during the growth of microplasmodia in the presence of colloidal chitin $\left(10 \mathrm{mg} \mathrm{ml}^{-1}\right)$ and assayed for $N$-acetylglucosamine $(O)$ as described in Methods. Microplasmodial protein (O) redrawn from Fig. 1 is given for comparison.

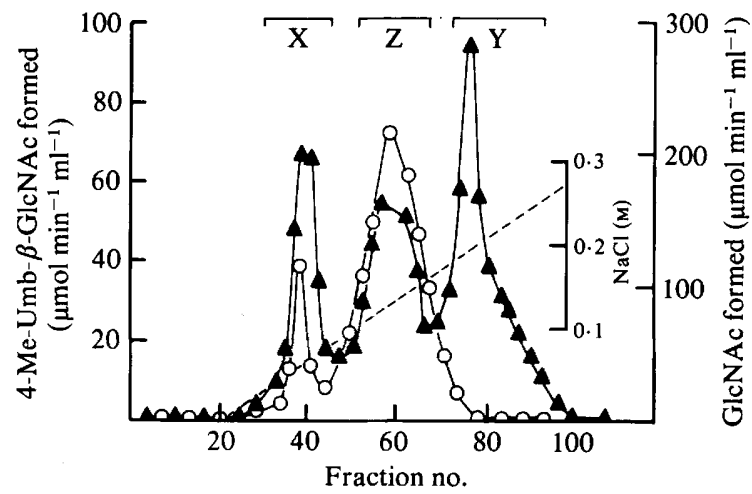

Fig. 3. Separation of $\beta$ - $N$-acetylhexosaminidases $\mathrm{X}, \mathrm{Y}$ and $\mathrm{Z}$ on DEAE-cellulose. Dialysed culture medium was applied to a column of DEAE-cellulose $(4.5 \times 2.1 \mathrm{~cm}$ diam. $)$ equilibrated with $10 \mathrm{mM}-$ sodium phosphate buffer, pH 8.0. After elution with $100 \mathrm{ml}$ of the same buffer, a linear gradient of $\mathrm{NaCl}$ was applied. Fractions $(5 \mathrm{ml})$ of the column eluate were assayed for $\beta$ - $N$-acetylhexosaminidase using 4-MeUmb- $\beta$-GlcNAc $(\boldsymbol{\Lambda})$ and $N, N^{\prime}$-diacetylchitobiose $(O)$ as substrates.

hexosaminidase, or clearly distinct activities, these enzymes were purified further using a combination of gel filtration and affinity chromatography on Concanavalin A-Sepharose 4B (Table 1).

\section{Comparison of $\beta$ - $N$-acetylhexosaminidases $X$ and $Z$}

The activities of $\beta$ - $N$-acetylhexosaminidases $X$ and $Z$ were compared using 4-MeUmb- $\beta$ GlcNAc and $N, N^{\prime}$-diacetylchitobiose as substrates. $\beta$ - $N$-Acetylhexosaminidase $\mathrm{X}$ had a symmetrical $\mathrm{pH}$ activity curve with an optimum at $\mathrm{pH} 4.5$ with $4-\mathrm{MeUmb}-\beta$-GlcNAc as substrate, whereas the optimum was pH 3.5 for hydrolysis of the disaccharide. $\beta$ - $N$-Acetylhexosaminidase $\mathrm{Z}$ had a broad $\mathrm{pH}$ activity curve with no clearly defined optimum when 4-MeUmb- $\beta$-GlcNAc was used as substrate. With $N, N^{\prime}$-diacetylchitobiose as the substrate the optimum was pH 4.0.

$K_{\mathrm{m}}$ values for $\beta$ - $N$-acetylhexosaminidases $\mathrm{X}$ and $\mathrm{Z}$ at $\mathrm{pH} 4.5$ with $4-\mathrm{MeUmb}-\beta$-GlcNAc as the substrate, were $0.80 \mathrm{mM}$ and $0.39 \mathrm{mM}$, respectively, whereas with $N, N^{\prime}$-diacetylchitobiose as

medium; $(d)$ chitinase activity assayed with ${ }^{3} \mathrm{H}$-labelled colloidal chitin and expressed per $\mathrm{ml}$ of medium; (e) $\beta$ - $N$-acetylhexosaminidase activity assayed with 4-MeUmb- $\beta$-GlcNAc and expressed per mg of microplasmodial protein; $(f)$ chitinase activity assayed with ${ }^{3} \mathrm{H}$-labelled colloidal chitin and expressed per $\mathrm{mg}$ of microplasmodial protein. 
Table 1. Purification of $\beta$ - $N$-acetylhexosaminidases $X$ and $Z$ from spent culture medium of $P$. polycephalum

Spent culture medium $(100 \mathrm{ml})$ was centrifuged to remove the slime and dialysed against 5 mM-sodium phosphate buffer, $\mathrm{pH} 8.0$, in preparation for DEAE-cellulose chromatography as described in Methods.

\begin{tabular}{|c|c|c|c|c|c|}
\hline Purification step & $\begin{array}{c}\text { Total } \\
\text { activity } \\
\left(\mu \mathrm{mol} \mathrm{min}^{-1}\right)\end{array}$ & $\begin{array}{l}\text { Total } \\
\text { protein } \\
\text { (mg) }\end{array}$ & $\begin{array}{c}\text { Specific } \\
\text { activity } \\
{\left[\mu \mathrm{mol} \mathrm{min}^{-1}\right.} \\
\left.(\mathrm{mg} \text { protein })^{-1}\right]\end{array}$ & $\begin{array}{c}\text { Recovery } \\
(\%)\end{array}$ & $\begin{array}{l}\text { Purification* } \\
\text { (fold) }\end{array}$ \\
\hline Crude extract & 6.9 & 458 & 0.015 & 100 & 1 \\
\hline DEAE-cellulose $\mathrm{X}$ & $0 \cdot 68$ & 10 & $0 \cdot 069$ & 10 & $4 \cdot 6$ \\
\hline Z & $0 \cdot 7$ & $7 \cdot 8$ & 0.091 & 10 & $6 \cdot 2$ \\
\hline $\mathrm{Y}$ & $1 \cdot 2$ & $1 \cdot 2$ & 0.95 & 17 & 65 \\
\hline Biogel P200 X & $1 \cdot 26$ & $1 \cdot 1$ & $1 \cdot 14$ & $18 \cdot 2$ & 76 \\
\hline Z & $1 \cdot 1$ & 0.38 & 1.4 & 16 & 93 \\
\hline Con A-Sepharose $\mathrm{X}$ & 0.69 & $0 \cdot 36$ & 1.9 & 10 & 128 \\
\hline $\mathrm{Z}$ & 0.58 & $0 \cdot 2$ & $2 \cdot 9$ & $8 \cdot 5$ & 193 \\
\hline
\end{tabular}

* The purification factors are arbitrary because the activities of all three $\beta$ - $N$-acetylhexosaminidases are included in the assay of the crude extract.
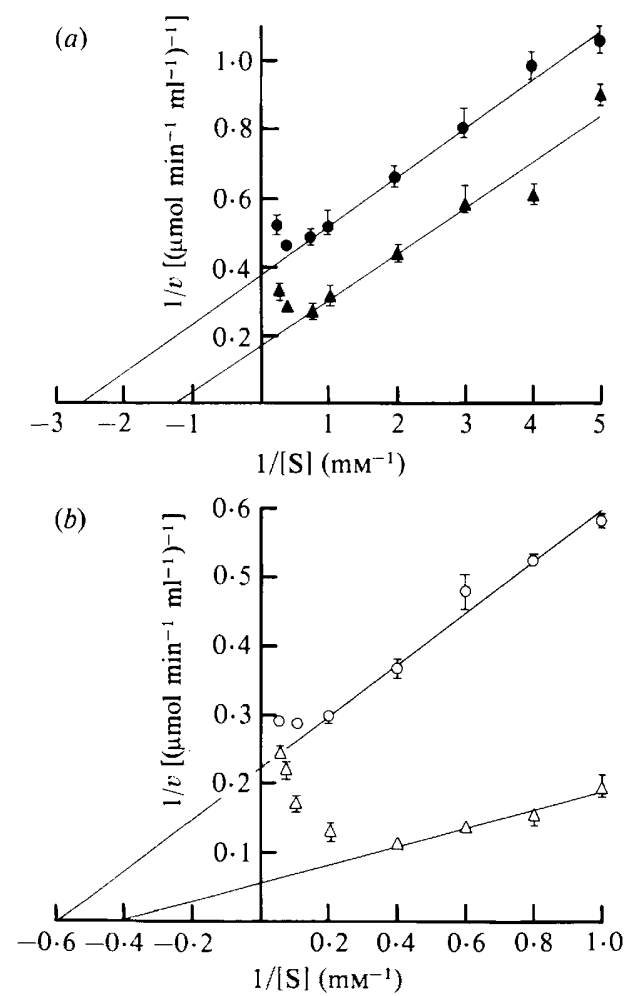

Fig. 4. Dependence of $\beta$ - $N$-acetylhexosaminidase activities on substrate concentration. (a) $\beta$ - $N$-Acetylhexosaminidases $X(\boldsymbol{\Lambda})$ and $Z(\Theta)$ assayed with $4-\mathrm{MeUmb}-\beta$-GlcNAc; $(b) \beta$ - $N$-acetylhexosaminidases $\mathrm{X}(\triangle)$ and $\mathrm{Z}(\mathrm{O})$ assayed with $N, N^{\prime}$-diacetylchitobiose. Values are means of triplicate determinations. Vertical lines through tile values represent the spread of activities where these fall outside the range covered by the symbol.

substrate and assayed at $\mathrm{pH} 3.8$, the $K_{\mathrm{m}}$ values were $2.5 \mathrm{mM}$ and $1.7 \mathrm{mM}$, respectively. $\beta-N$ Acetylhexosaminidases $X$ and $Z$ both exhibited substrate inhibition at 4-MeUmb- $\beta$-GlcNAc and $N, N^{\prime}$-diacetylchitobiose concentrations greater than $2.5 \mathrm{~mm}$ (Fig. $4 a, b$ ). Half-lives of $\beta-N$ - 
Table 2. Comparison of the substrate specificities of $\beta$ - $N$-acetylhexosaminidases $X$ and $Z$

Assays were performed in $0 \cdot 1 \mathrm{M}$-sodium phosphate/citric acid buffer, $\mathrm{pH} 3 \cdot 8$, as described in Methods, except for those in which 4-MeUmb- $\beta$-GlcNAc was the substrate which were carried out at pH 4.6. Values are the means of duplicate determinations.

\begin{tabular}{|c|c|c|c|}
\hline \multirow[b]{2}{*}{ Substrate } & \multirow{2}{*}{$\begin{array}{c}\text { Concn } \\
(\mathrm{mM})\end{array}$} & \multicolumn{2}{|c|}{$\begin{array}{c}\beta \text { - } N \text {-Acetylhexosaminidase activity } \\
{\left[\mu \mathrm{mol} \mathrm{min}^{-1}(\mathrm{ml} \text { enzyme preparation })^{-1}\right]}\end{array}$} \\
\hline & & $\mathbf{X}$ & $\mathbf{Z}$ \\
\hline 4-MeUmb- $\beta$-GlcNAc & $1 \cdot 3$ & 22 & 12 \\
\hline$N, N^{\prime}$-Diacetylchitobiose & $4 \cdot 7$ & 23 & 27 \\
\hline $\begin{array}{l}N, N^{\prime}, N^{\prime \prime} \text {-Triacetylchito- } \\
\text { triose }\end{array}$ & $4 \cdot 7$ & 11 & 15 \\
\hline $\begin{array}{l}\text { 3,4-Dinitrophenyl- } \beta-N \text { - } \\
\text { diacetylchitobioside }\end{array}$ & $0 \cdot 1$ & $5 \cdot 4$ & $3 \cdot 1$ \\
\hline $\begin{array}{l}\text { 3,4-Dinitrophenyl- } \beta-N \text { - } \\
\text { tetracetylchitotetrao- } \\
\text { side }\end{array}$ & $0 \cdot 1$ & 0 & 1.4 \\
\hline
\end{tabular}

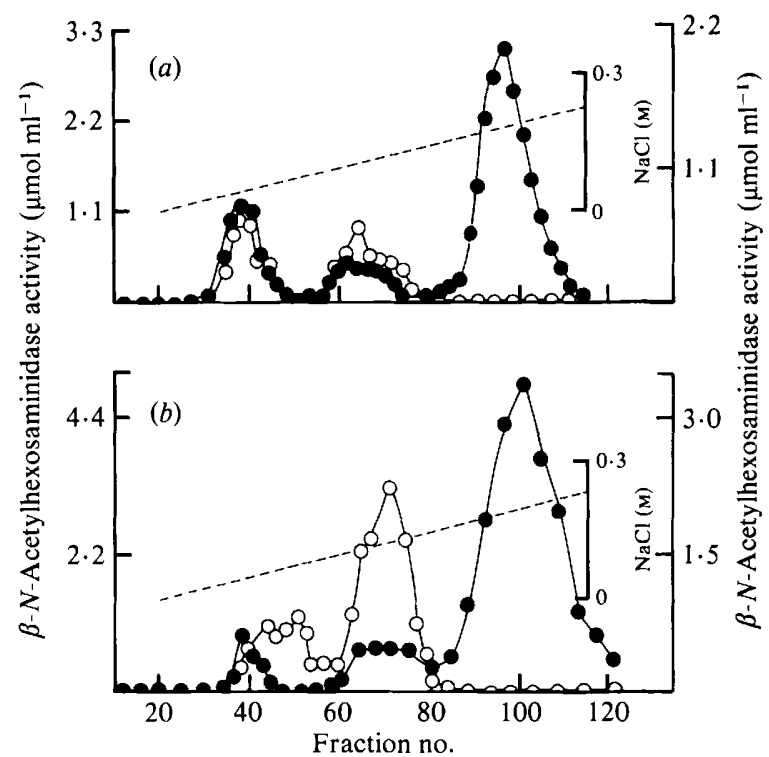

Fig. 5. Separation of $\beta$ - $N$-acetylhexosaminidase activities in the culture medium (a) and microplasmodia $(b)$. The culture was harvested during exponential growth, prepared for chromatography as described in Methods and all the activity in each preparation separated on columns of DEAE-cellulose. Fractions $(6 \mathrm{ml})$ were assayed for $\beta$ - $N$-acetylhexosaminidase activity using 4-MeUmb- $\beta$-GlcNAc (O) and $N, N^{\prime}$-diacetylchitobiose $(O)$ as substrates.

acetylhexosaminidase $\mathrm{X}$ and $\mathrm{Z}$ at $70^{\circ} \mathrm{C}$ were $30 \mathrm{~min}$ and $50 \mathrm{~min}$, respectively, irrespective of whether 4 -MeUmb- $\beta$-GlcNAc or $N, N^{\prime}$-diacetylchitobiose was used as substrate.

Comparison of the substrate specificities of $\beta$ - $N$-acetylhexosaminidases $X$ and $Z$

$\beta$ - $N$-Acetylhexosaminidases $X$ and $Z$ were tested for their activities towards synthetic and naturally occurring substrates (Table 2). $\beta$ - $N$-Acetylhexosaminidase $\mathrm{X}$ was twice as active as $\beta$ $N$-acetylhexosaminidase $\mathrm{Z}$ with $4-\mathrm{MeUmb}-\beta$-GlcNAc as a substrate, when their activities towards $N, N^{\prime}$-diacetylchitobiose were taken as standards for comparison. It also hydrolysed 3,4dinitrophenyl-di- $N$-acetylchitobioside at a greater rate. However, $\beta$ - $N$-acetylhexosaminidase X had no detectable activity towards 3,4-dinitrophenyl- $\beta$-tetra- $N$-acetylchitotetraoside, while $\beta$ - $N$ acetylhexosaminidase $\mathrm{Z}$ liberated 3,4-dinitrophenol from this substrate at half the rate measured with the 3,4-dinitrophenyl-di- $N$-acetylchitobioside. 


\section{Distribution of isoenzymes between culture medium and organism}

Kuehn et al. (1977) suggested that $\beta$ - $N$-acetylhexosaminidase $X$ corresponded to the form they regarded as extracellular in its location and form $Y$ to the intracellular form. In order to verify this, and to establish the distribution of form $\mathrm{Z}, \beta$ - $N$-acetylhexosaminidases $\mathrm{X}, \mathrm{Y}$ and $\mathrm{Z}$ were separated by DEAE-cellulose chromatography of culture medium and a microplasmodial extract, obtained from a culture growing exponentially (Fig. 5). The activities of $\beta$ - $N$-acetylhexosaminidase $X$ in the culture medium (after removal of microplasmodia) and in the microplasmodia were $10 \cdot 1$ units and 4.4 units, respectively; for form $Z$ they were 5.6 units and 10.7 units and for form $Y$ they were 35 units and 85 units, using 4-MeUmb- $\beta$-GlcNAc as the substrate.

\section{DISCUSSION}

During the axenic culture of $P$. polycephalum there is an accumulation of $\beta$ - $N$-acetylhexosaminidase and chitinase in the medium and from experiments in which chitin was added to the culture medium it is evident that these enzymes can participate in the complete hydrolysis of the polymer. The activity of chitinase seems to be the limiting factor in the depolymerization of chitin, since we were unable to find evidence for the presence of chitin oligosaccharides and $\mathrm{N}$ acetylglucosamine was the only product. It would appear that $\mathrm{N}$-acetylglucosamine is not used for growth since the maximum concentration of the sugar in the medium was exactly that expected from complete depolymerization of the chitin but the decrease in concentration of $\mathrm{N}$ acetylglucosamine that coincides with the onset of spherulation is consistent with its utilization during differentiation.

Culture of microplasmodia in the presence of chitin caused a fourfold increase in the activity of $\beta$ - $N$-acetylhexosaminidase over that obtained in the standard axenic medium, which was ten times greater when expressed as a function of the biomass measured as protein. There was no difference in the chitinase activity under these conditions. The physiological basis of the enhanced specific activity during early stages of growth is not known; it seems likely that the presence of $\mathrm{N}$-acetylglucosamine in the medium might be a contributory factor, but not the only one. When microplasmodia were grown in a medium containing $N$-acetylglucosamine instead of glucose (results not shown) there was an increase in the specific activity of $\beta$ - $N$-acetylhexosaminidase in the medium, but only one-seventh of that observed in the presence of chitin.

According to Kuehn et al. (1977) the extracellular and intracellular forms of $\beta$ - $N$-acetylhexosaminidases from $P$. polycephalum differ in their physical and immunochemical properties and in their substrate specificities and may be the products of distinct structural genes. Their suggestion that $\beta$ - $N$-acetylhexosaminidase $\mathrm{X}$ is the extracellular form and $\mathrm{Y}$ the intracellular form is consistent with their behaviour on DEAE-cellulose, but since the more acidic of these peaks of $\beta$ - $N$-acetylhexosaminidase was resolved into two distinct forms, $\mathrm{Y}$ and $\mathrm{Z}$, it is not clear whether the intracellular enzyme of Kuehn et al. (1977) is form Y, Z or a mixture of both. Analysis of the pattern of isoenzymes on DEAE-cellulose chromatography revealed that the culture medium and cellular material both had $\beta$ - $N$-acetylhexosaminidases $\mathrm{X}, \mathrm{Y}$ and $\mathrm{Z}$, but in diff erent proportions. Cultures were sampled during exponential growth in order to minimize microplasmodial lysis which is brought about more readily in stationary phase cultures, but we were unable to obtain a clear separation of the forms on the basis of their distribution between the medium and the cellular material, although over twice as much form $\mathrm{X}$ was in the medium as in the microplasmodia. Intracellular form $\mathrm{Z}$ had much greater activity towards $N, N^{\prime}$-diacetylchitobiose than its counterpart in the medium.

All three $\beta$ - $N$-acetylhexosaminidases bound to Concanavalin A-Sepharose and were eluted with $\alpha$-methylglucoside, behaviour which indicates that they are glycoproteins. Their binding to the immobilized lectin is in contrast to their behaviour in Ouchterlony double diffusion experiments, when the extracellular and intracellular enzymes did not form precipitin lines with Concanavalin A (Kuehn et al., 1977).

$\beta$ - $N$-Acetylhexosaminidase $\mathrm{Y}$ can be clearly distinguished from the other forms by its lack of activity towards $N, N^{\prime}$-diacetylchitobiose, a feature of its specificity that precludes it from a role 
in chitin degradation. While $\beta$ - $N$-acetylhexosaminidases $\mathrm{X}$ and $\mathrm{Z}$ share the ability to hydrolyse the disaccharide, they differ in their $\mathrm{pH}$ optima, $K_{\mathrm{m}}$ values and their rates of denaturation at $70{ }^{\circ} \mathrm{C}$. Both enzymes exhibit marked inhibition by $4-\mathrm{MeUmb}-\beta$-GlcNAc and $N, N^{\prime}$-diacetylchitobiose, an unusual feature of $\beta$ - $N$-acetylhexosaminidase activity, but one that is observed with the $\alpha$-D-galactosidase from this organism (Kilpatrick \& Stirling, 1977). The chromogenic substrate 3,4-dinitrophenyl-tetra- $N$-acetylchitotetraoside was hydrolysed by $\beta$ - $N$-acetylhexosaminidase $\mathrm{Z}$ but not by form $\mathrm{X}$, which may indicate that the former enzyme has a preference for larger chitin oligosaccharides.

We thank the SRC for the award of a CASE studentship to G. A. C.

\section{REFERENCES}

Braun, V. \& Behrens, K. (1996). A ribonuclease from Physarum. Biochemical properties and synthesis in the mitotic cycle. Biochimica et biophysica acta 195, 87-98.

Carlile, M. J. (1971). Myxomycetes and other slime moulds. Methods in Microbiology 4, 237-265.

FARR, D., Horisberger, M. \& Jolles, P. (1974). An extracellular rennin-like enzyme produced by $P h y$ sarum polycephalum. Biochimica et biophysica acta 334, $410-416$.

KiLPATRICK, D. C. \& STIRLING, J. L. (1975). Two forms of $\beta-N$-acetylhexosaminidase from Physarum polycephalum. Biochemical Society Transactions 3, 246247.

Kilpatrick, D. C. \& Stirling, J. L. (1977). Glyco-

sidases from the culture medium of Physarum polycephalum. Biochemical Journal 161, 149-160.

Kuehn, G. D., Williams, R. C., Cox, M. K. \& JACKSON, J. C. (1977). Intracellular and extracellular $\beta$ - $N$-acetylhexosaminidases from Physarum polycephalum. Archives of Biochemistry and Biophysics 183, 686-699.

Molano, J., Duran, A. \& Cabib, E. (1977). A rapid and sensitive assay for chitinase using tritiated chitin. Analytical Biochemistry 83, 648-656.

Reissig, J. L., Strominger, J. L. \& Leloir, L. F. (1965). A modified colorimetric method for the estimation of $\mathrm{N}$-acetylamino sugars. Journal of Biological Chemistry 217, 959-966. 